\title{
BAGAIMANA KESEJAHTERAAN SUPIR BIS TERGANTUNG DUKUNGAN KELUARGA?
}

\author{
Muhammad Dudih Fadilah Hamdi, Gemala Nurendah \\ Departemen Psikologi, Universitas Pendidikan Indonesia \\ Email: muhammaddudi@gmail.com
}

\begin{abstract}
The purpose of this study was to examine the effect of family support perception on fatigue and subjective well-being of the bus drivers. The research method used was a quantitative research with 125 bus driver participants. The instrument were Perceived Social Support from family or PSS-Fa (Procidano \& Heller, 1983) to measure family support, Fatigue Measurement Scale or SPK to measure fatigue, Scale of Positive and Negative Experience (SPANE) instrument and Satisfaction With Life Scale (SWLS) to measure subjective well-being. Technique of data analysis was used simple regression. The results of this study indicated that family support affected fatigue with a significance level of 0.000; and family support influenced subjective well-being with significance level of 0.01.
\end{abstract}

Key words: Family Support, Fatigue, Subjective Well-being, Bus Drivers.

\begin{abstract}
Abstrak
Tujuan dari penelitian kuantitatif ini adalah untuk menguji dampak persepsi dukungan keluarga pada kelelahan dan kesejahteraan subyektif kepada pengemudi bus. Metode penelitian yang digunakan adalah penelitian kuantitatif dengan 125 peserta sopir bus. Instrumen yang digunakan adalah dukungan sosial yang dirasakan dari keluarga atau PSS-Fa (Procidano \& Heller, 1983) untuk mengukur dukungan keluarga, instrumen Skala Pengukuran Kelelahan atau SPK untuk mengukur kelelahan, skala instrumen pengalaman positif dan negatif (SPANE) dan Skala Kepuasan Hidup (SWLS) untuk mengukur kesejahteraan subjektif. Teknik analisis yang digunakan adalah regresi sederhana. Hasil penelitian ini menunjukkan bahwa dukungan keluarga mempengaruhi kelelahan dengan nilai signifikansi 0,000; dan dukungan keluarga memengaruhi kesejahteraan subjektif dengan nilai signifikan 0,01 .
\end{abstract}

Kata kunci: Dukungan keluarga, Kelelahan, Kesejahteraan Subjektif, Supir Bis

\section{PENDAHULUAN}

Menurut Direktorat Jenderal Perhubungan, Kemenhub mengatakan bahwa kecelakaan bis yang terjadi pada 2016 sebanyak 148 kasus dan terus meningkat setiap tahunnya (Dephub, 2016). Berdasarkan wawancara ke salah satu supir bus di Terminal Cicaheum-Bandung, pekerjaan yang dilakukannya dapat dilakukan lebih dari lima jam sehingga dapat menyebabkan kelelahan fisik 
dalam bentuk nyeri otot. Situasi lalu lintas dalam perjalanan pun seringkali menyita waktu pengemudi bus untuk beristirahat. Jarak yang sangat jauh dan harus ditempuh sekitar 360 kilometer dan memakan waktu sekitar 16 jam untuk ditempuh setiap hari. Selain itu, lubang dan jalan berliku serta kurangnya rambu-rambu lalu lintas membutuhkan fokus yang tinggi dalam mengemudikan bus. Situasi kerja yang monoton dan lama secara signifikan memengaruhi kewaspadaan pengemudi terhadap lalu lintas dan penurunan kualitas kerja. Oleh karena itu, pengemudi bus memiliki risiko serius akibat efek kelelahan dari tuntutan pekerjaan yang melibatkan jam kerja yang panjang. Dampak kelelahan dapat menyebabkan kecelakaan (Kee, 2010).

Kelelahan mengakibatkan penurunan kinerja karena beban kerja yang berkepanjangan. Menurut Kennedy (2013), kelelahan adalah penurunan kinerja yang terjadi pada intensitas kerja yang tinggi atau berulang. Kelelahan juga merupakan penurunan konsentrasi yang dapat diukur dengan selektivitas dan kapasitas terhadap perhatian. Definisi kelelahan adalah situasi tubuh yang tidak sadar akan ketidakmampuan untuk melakukan aktifitas yang cukup, berhubungan dengan daya yang dihabiskan. Oleh karena itu, kelelahan adalah kurangnya energi dan motivasi yang ditandai oleh rasa kantuk dan perasaan acuh tak acuh terhadap keadaan saat ini. Secara fisiologis, kelelahan mengakibatkan kontraksi otot. Sebuah penelitian menemukan bahwa semakin lama orang bekerja akan menyebabkan kelelahan yang akan berdampak pada kinerja yang cenderung memburuk terutama jika kurang tidur (Yun Kyung Kim \& C, 2015).

Aspek psikologis lain yang juga penting bagi karyawan adalah kesejahteraan subjektif. Kesejahteraan subyektif adalah suatu kondisi yang cenderung stabil sepanjang hidup terhadap penilaian diri karena itu akan menentukan kebahagiaan. Kesejahteraan subyektif adalah evaluasi subjektif dari kehidupan di mana ia mengalir, seperti kepuasan hidup, kepuasan perkawinan, pekerjaan, dan emosi yang menyenangkan dan rendahnya tingkat emosi yang tidak menyenangkan (Diener et al, 1999).

Proses kesejahteraan subyektif melibatkan evaluasi kognitif dan afektif. Evaluasi kognitif adalah penilaian kepuasan hidup, sedangkan evaluasi afektif adalah respons emosional yang muncul dari kepuasan hidup. Respons emosional yang muncul terdiri dari respons emosional positif misalnya perasaan senang dan respons emosional negatif misalnya perasaan sedih atau cemas (Hanggoro, 2015). Kesejahteraan individu dirasakan berdasarkan kepuasan hidup daripada keseimbangan antara kognitif dan afektif. Kesejahteraan subyektif dapat mempengaruhi fungsi fisiologis. Individu yang sering merasakan emosi positif akan cepat pulih setelah kelelahan. Oleh karena itu, emosi positif akan muncul langsung pada peningkatan kesehatan fisiologis (Kuykendall $\&$ Tay, 2015).

Hasil penelitian Russo Shteigman dan Carmeli (2016) menunjukkan bahwa dukungan keluarga dapat membantu individu untuk meningkatkan kesejahteraan dan menghasilkan energi positif di tempat kerja. Nahum-Shani, Bamberger dan Bacharach (2011) juga menemukan bahwa dengan membangkitkan perasaan positif, peningkatan penghargaan, dan pola pertukaran positif dapat 
menambah manfaat psikologis yang terkait dengan penerima dukungan emosional yang mengarah pada peningkatan kesejahteraan selama dukungan emosional menerima kenaikan.

Hubungan antara karyawan dan keluarga sangat penting untuk menjaga energi positif karyawan, termasuk pengemudi bis. Dukungan keluarga yang tinggi akan meningkatkan motivasi kerja yang tinggi (Russo, Shteigman \& Carmeli, 2016). Menurut Nahum-Shani, Bamberger dan Bacharach (2011) menemukan bahwa perasaan positif, peningkatan penghargaan dan pola timbal balik dari pertukaran positif terutama pada dukungan emosional akan meningkatkan kesejahteraan subyektif.

Persepsi dukungan keluarga melibatkan proses kognitif untuk menilai kualitas dukungan sosial keluarga. Dukungan keluarga memberikan dukungan yang diberikan kepada keluarga dalam bentuk layanan, pertanyaan, saran, barang yang dapat membuat anggota keluarga merasa aman dan nyaman (Susilawati, 2013). Dukungan keluarga dapat dilihat dari perasaan memiliki kepada keluarga dan bagaimana keluarga merasakan dukungan yang terdiri dari dukungan berbagai anggota keluarga dan dukungan terhadap peran anggota keluarga (Hung, dkk., 2017).

Menurut Kyzar, dkk., (2012), dukungan keluarga adalah strategi yang diarahkan untuk membantu anggota keluarga, untuk memberikan panduan kepada anggota lainnya. Dukungan keluarga tergantung pada persepsi penerimaan yang diberikan oleh keluarga. Berdasarkan permasalahan yang ditemui oleh para supir bis yang cenderung mengalami kelelahan dalam bekerja maka peneliti melakukan penelitian dengan judul "Apakah Supir Bis Membutuhkan Dukungan Keluarga Dalam Bekerja?”

\section{METODE}

Penelitian ini menggunakan pendekatan kuantitatif dengan total responden 125 partisipan. Populasi dalam penelitian ini adalah sopir bis Antar Kota Antar Provinsi atau sopir bis yang bekerja lebih dari 8 jam. Pengambilan data dilakukan di terminal-terminal bis di sekitar Kota Bandung. Teknik pengambilan sampel adalah menggunakan sampling incidental. Analisis data penelitian menggunakan teknik analisis regresi. Model penelitian ini digambarkan oleh bagan berikut ini:

Alat ukur penelitian ini diujicobakan kepada 50 supir angkutan perkotaan di Bandung. Alat ukur kelelahan terdiri dari 10 aitem yang mengukur aspek motivasi, fisik dan mental. Uji reliabilitas menghasilkan skor sebesar 0,76. Instrumen kesejahteraan subjektif menggunakan 6 aitem yang mengukur kesejahteraan subjektif (SWLS) dan 12 aitem mengukur afek positif dan afek negative (SPANE) dari Diener, dkk. (1999). Hasil uji reliabilitas menunjukkan aitem-aitem kesejahteraan subjektif memiliki skor 0.67 dan skor untuk aspek positif adalah 0.68 serta skor untuk afek negatif sebesar 0.76. Persepsi terhadap dukungan keluarga menggunakan alat ukur dukungan sosial keluarga (PSS-FA) yang memiliki 20 item yang dikembangkan oleh (Procidano 
\& Heller, 1983) yang mengukur aspek dukungan, umpan balik dan informasi. Hasil uji menunjukkan bahwa alat ukur ini memiliki skor 0.67 .

\section{HASIL}

Berdasarkan tabel 2 dapat dikatakan bahwa supir bis Antar Kota Antar Provinsi yang menjadi sampel pada penelitian ini menghayati bahwa keluarga mereka mendukung mereka dalam bekerja, merasa cukup sejahtera dan kelelahan dalam bekerja yang masih dapat diatasi.

Tabel 1

Uji Perbedaan pada Variabel Demografi

\begin{tabular}{ccccccc}
\hline \multirow{2}{*}{ Demografi } & \multicolumn{2}{c}{ Kelelahan } & \multicolumn{2}{c}{$\begin{array}{c}\text { Kesejateraan } \\
\text { Subjektif }\end{array}$} & \multicolumn{2}{c}{$\begin{array}{c}\text { Dukungan } \\
\text { Keluarga }\end{array}$} \\
\cline { 2 - 7 } & $\mathbf{F} / \mathbf{t}$ & $\mathbf{p}$ & $\mathbf{F} / \mathbf{t}$ & $\mathbf{p}$ & $\mathbf{F} / \mathbf{t}$ & $\mathbf{p}$ \\
\hline Usia & 1.010 & .314 & -1.434 & .154 & -1.27 & .206 \\
Lama kerja & .065 & .937 & .176 & .839 & 1.430 & .243 \\
Waktu kerja & .447 & .505 & 2.163 & .144 & .315 & .576 \\
Jarak tempuh (KM) & 2.816 & .064 & 2.952 & .056 & 1.284 & .281 \\
Pendidikan & 1.873 & .138 & .447 & .720 & 3.229 & $.025^{*}$ \\
Penghasilan & .512 & .675 & 30.834 & $.000^{*}$ & 1.522 & .212 \\
\hline
\end{tabular}

Berdasarkan analisis statistik, pengemudi bus merasakan kelelahan yang sama, tidak ada perbedaan berkaitan dengan usia, lama kerja, waktu kerja, jarak tempuh, pendidikan dan penghasilan. Kesejahteraan subjektif sopir berbeda karena pendapatan dan dukungan keluarga sopir berbeda karena tingkat pendidikan. Kesejahteraan subjektif dipengaruhi pendapatan karena pendapatan berkorelasi dengan kesejahteraan subyektif seseorang (Veenhoven, 2000). Wulansari (2014) menyatakan bahwa perjalanan hidup dan tanggung jawab yang dibebankan selama hidup tidak selalu sesuai dengan gaji yang didapat yang kemudian memengaruhi kesejahteraan diri seseorang. Demikian pula dengan pengemudi bis yang menganggap kesejahteraan mereka muncul karena penghasilan yang mereka peroleh dari pekerjaan mereka. Individu yang tidak dapat memenuhi kebutuhan dasar dalam keadaan sosial dan ekonomi yang buruk dapat mengalami perasaan tertekan ketika berjuang untuk meningkatkan keterampilan hidup lingkungan mereka. Status ekonomi selain dapat berpengaruh terhadap kesejahteran juga menentukan kualitas hidup.

Hasil perhitungan untuk vaiabel dukungan keluarga menunjukan bahwa variabel ini dipengaruhi oleh tingkat pendidikan. Hal ini sejalan dengan pendapat dari Akbar (2015) yang menyebutkan bahwa faktor yang dapat mempengaruhi perbedaan persepsi adalah tingkat pendidikan. Persepsi secara umum adalah proses orang dalam mengatur, menginterpretasikan, dan memberikan makna terhadap informasi sensoris. Persepsi juga muncul karena perasaan, 
kemampuan berpikir, dan pengalaman masing-masing individu. Jadi tingkat pendidikan sopir bis dapat memengaruhi persepsi mereka atas dukungan keluarga yang diberikan.

Tabel 2.

Uji Signifikansi Pengaruh Dukungan Keluarga

Kepada Kelelahan dan Kesejahteraan Subjektif

\begin{tabular}{llccc}
\hline $\begin{array}{l}\text { Variabel } \\
\text { Independen }\end{array}$ & Variabel Dependen & $\mathrm{p}$ & $\mathrm{R}$ & $\mathrm{R}^{2}$ \\
\hline Dukungan & Kelelahan & .000 & .391 & .152 \\
\cline { 2 - 5 } Keluarga & Kesejahteraan Subjektif & .001 & .299 & .090 \\
\hline
\end{tabular}

Menurut Gulacti (2010) dukungan sosial yang dirasakan diterima dari seorang teman atau dari orang khusus tidak dapat menentukan kesejahteraan subjektif. Namun, hanya dukungan keluarga yang dirasakan 'spesial' oleh individu yang dapat memprediksi kesejahteraan subjektif. Dukungan emosional dari keluarga adalah dapat memprediksi secara positif meningkatkan kinerja dan untuk mencapai kepuasan hidup (Presti, Aloisio, \& Pluviano, 2010). Penilaian afektif dan kognitif dapat menentukan kualitas hidup dan mempengaruhi fungsi fisiologis (Kuykendall \& Tay, 2015; Veenhoven, 2000).

Persepsi dukungan keluarga juga mempengaruhi kelelahan pada pengemudi bis. Menurut Watanabe, dkk., (2017) terdapat efek tidak langsung dari banyak keluhan yang hanya dapat dikomunikasikan kepada pasangan. Dengan demikian, peran seorang istri sangat diperlukan untuk mengurangi kelelahan akibat kerja yang dialami oleh suami. Sedangkan bagi seorang pria yang tidak memiliki istri, dukungan orang tua tidak memiliki terlalu banyak pengaruh terhadap kelelahan. Dimensi yang memiliki skor tinggi untuk variabel kelelahan terdapat pada dimensi fisik.

Pada variabel persepsi dukungan keluarga, skor yang tinggi adalah untuk dimensi informasi. Dukungan ini membantu pekerja untuk mengatasi situasi yang bermasalah dengan memberikan informasi tentang masukan yang harus dilakukan. Dukungan ini memberikan solusi dan mengurangi stress terhadap suatu masalah dengan cara memberikan waktu luang bagi supir bis maupun anggota keluarganya (King dkk, 1995).

Selain itu, persepsi tentang dukungan keluarga juga mempengaruhi kesejahteraan subyektif dari pengemudi bis dengan skor yang tertinggi ada pada dimensi afektif positif. Afek positif merepresentasikan emosi yang menyenangkan pada diri sopir bus. Emosi positif bagian dari kesejahteraan positif karena emosi tersebut merefleksikan reaksi individu terhadap kejadian yang menunjukkan hidupnya berjalan sesuai dengan yang diinginkan (Diener dkk, 2009).

Kesimpulan dari penelitian ini adalah dukungan keluarga memengaruhi kelelahan dan kesejahteraan subjektif pada supir bis Antar Kota Antar Provinsi. peneliti memberikan 
rekomendasi kepada pihak yang berkaitan supir bis yaitu perusahaan bis dan keluarga agar dapat menyusun strategi untuk mengurangi kelelahan atas pekerjaan serta meningkatkan kesejahteraan subjektif. Keterbatasan dalam penelitian ini adalah kemampuan supir bis dalam memahami isi dari pernyataan dalam kuesioner yang juga beragam. Pengambilan data pun cukup menyulitkan karena harus dilakukan secara individual di lokasi yang kurang kondusif (terminal).

\section{DAFTAR PUSTAKA}

Akbar, R. F. (2015). Analisis Persepsi Pelajar Tingkat Menengah Pada Sekolah Tinggi Agama Islam Negeri Kudus. Jurnal Penelitian Pendidikan Islam, 10(1), 189-210.

Dephub. (2016). Jumlah Kecelakaan Bus Tahun Ini Menurun, Ini Penyebabnya. Retrieved December 6, 2017, from http://www.dephub.go.id/post/read/jumlah-kecelakaan-bus-tahunini-menurun,-ini-penyebabnya

Diener, E., Suh, E. M., Lucas, R. E., \& Smith, H. L. (1999). Subjective well-being: Three decades of progress. Psychological Bulletin. https://doi.org/10.1037/0033-2909.125.2.276

Gulacti, F. (2010). The effect of perceived social support on subjective well-being. Procedia Social and Behavioral Sciences, 2(2), 3844-3849. https://doi.org/10.1016/j.sbspro.2010.03. 602

Hanggoro, Y. (2015). Fakultas psikologi program studi psikologi universitas sanata dharma 2015.

Hung, M., Bounsanga, J., Voss, M. W., Crum, A. B., Chen, W., \& Birmingham, W. C. (2017). The relationship between family support; pain and depression in elderly with arthritis. Psychology, Health \& Medicine, 22(1), 75-86. https://doi.org/10.1080/13548506.2016. 1211293

Hurlock, Elizabeth .B. 1992. Developmental Psycology: A Life Span Approach, fifth edition. Mc Graw Hill.

Islam, M. H., \& Muhammad, N. (2018). Does Fatigue Correlate to Age , Educational Qualification, and Income? International Journal of Social Science an Humanities Research, 6(2), 13-20.

Kee, S. (2010). Driving Fatigue and Performance among Occupational Drivers in Simulated Prolonged Driving. Journal of Health Science, 2(1), 167-177.

Kennedy, H. G. (2013). Fatigue and fatigability. Psychiatric Bulletin, (December), 1-5. https://doi.org/10.1192/bjp.153.1.1

Kuykendall, L., \& Tay, L. (2015). Employee subjective well-being and physiological functioning : An integrative model. Journal of Health Psychology Open. https://doi.org/10.1177/ 2055102915592090 
Kyzar, K. B., Turnbull, A. P., Summers, J. A., \& Gomez, V. A. (2012). The Relationship of Family Support to Family Outcomes: A Synthesis of Key Findings from Research on Severe Disability. Research and Practice for Persons with Severe Disabilities, 37(1), 31-44. https://doi.org/10.2511/027494812800903247

Muslim, E., Moch, B. N., Puspasari, M., \& Siregar, R. A. (2015). Fatigue Measurement of Driving Activity on Male Motorcycle Drivers based on Cognitive , Physiological , and Subjective Approaches. International Journal of Technology, (September 2016). https://doi.org/ 10.14716/ijtech.v6i6.1439

Nahum-Shani, I., Bamberger, P. A., \& Bacharach, S. B. (2011). Social support and employee wellbeing: The conditioning effect of perceived patterns of supportive exchange. Journal of Health and Social Behavior, 52(1), 123-139. https://doi.org/10.1177/0022146510395024

Presti, A. Lo, Aloisio, F. D., \& Pluviano, S. (2010). With a Little Help From My Family : A MixedMethod Study on the Outcomes of Family Support and Workload. Europe's Journal of Pshychology. https://doi.org/10.5964/ejop.v12i4.1159

Procidano, M. E., \& Heller, K. (1983). Measures of perceived social support from friends and from family: Three validation studies. American Journal of Community Psychology, 11(1), 1-24. https://doi.org/10.1007/BF00898416

Russo, M., Shteigman, A., \& Carmeli, A. (2016). Workplace and family support and work-life balance: Implications for individual psychological availability and energy at work. Journal of Positive Psychology, 11(2), 173-188. https://doi.org/10.1080/17439760.2015.1025424

Susilawati, D. (2013). Hubungan Antara Dukungan Keluarga dengan Tingkat Kecemasan Penderita Kanker Serviks Paliatif di RSUP Dr Sardjito Yogyakarta. Ilmu Keperawatan, 4(2), 87-99.

Thompson, C. A., \& Prottas, D. J. (2006). Relationships among organizational family support, job autonomy, perceived control, and employee well-being. Journal of Occupational Health Psychology, 11(1), 100-118. https://doi.org/10.1037/1076-8998.10.4.100

Veenhoven, R. (2000). The four qualities of life. Journal of Happiness Studies, 1-39.

Watanabe, M., Shimazu, A., Bakker, A. B., Demerouti, E., Shimada, K., \& Kawakami, N. (2017). The impact of job and family demands on partner's fatigue : A study of Japanese dual-earner parents, 1-12. https://doi.org/10.1371/journal.pone.0172291

Wulansari, N. (2014). Kesejahteraan Subjektif pada Guru Bantu SD Surakarta.

Yun Kyung Kim, N. H. C., \& C, N. H. (2015). Correlations among occupational stress , fatigue, and depression in call center employees in Seoul. Journal of Physical Therapy Science, (1). 